\title{
PEMILIHAN METODE KONTRASEPSI OLEH IBU AKSEPTOR KB
}

\author{
Fachrudi Hanafi \\ Fakutas Kedokteran Universitas Islam Al-Azhar \\ J1. Unizar No. 20 Turida Mataram \\ Email: rudi_pskk@yahoo.co.id
}

\begin{abstract}
ABSTRAK
Latar belakang : Makin banyak jenis metode kontrasepsi yang tersedia saat ini akan makin banyak pula pilihan yang dapat dilakukan oleh masyarakat dalam memilih metode kontrasepsi. Metode kontrasepsi yang banyak jenisnya ini akan menyebabkan banyak ibu pasca salin mengalami kesulitan dalam menentukan pilihan jenis kontrasepsi yang akan digunakan.

Tujuan penelitian : mengetahui faktor-faktor dalam pemilihan metode kontrasepsi oleh ibu akseptor KB. Metode : Jenis penelitian ini adalah observasional deskriptif dengan rancangan cross sectional. Populasi pada penelitian ini adalah jumlah akseptor KB selama tahun 2015 di Puskesmas Karang Taliwang sebanyak 372 orang. Jumlah sampel penelitian ini adalah seluruh akseptor KB yang melakukan kunjungan ke Puskesmas dengan jumlah 30 orang. Metode pengambilan sampel secara accidental sampling. Data primer didapatkan melalui wawancara mendalam/depth interview dengan responden. Pengolahan data dilakukan secara deskriptif.

Hasil : pemilihan alat kontrasepsi oleh ibu akseptor KB di

pengaruhi oleh pengetahuan yang kurang sebanyak 21 orang (70\%), tidak adanya pengaruh sosial budaya sebanyak 29 orang $(96,6 \%)$, tidak adanya faktor agama sebanyak 26 orang $(86,6 \%)$, adanya faktor biaya sebanyak 30 orang (100\%), adanya faktor dukungan keluarga sebanyak 30 orang $(100 \%)$ dan adanya faktor pendapatan keluarga 29 orang $(96,6 \%)$.

Kesimpulan : Dari semua faktor yang mempengaruhi pemilihan tersebut yang paling dominan adalah dukungan keluarga, biaya dan pendapatan keluarga.
\end{abstract}

Kata Kunci : Pemilihan Metode Kontrasepsi, Ibu Akseptor KB.

\section{PENDAHULUAN}

Metode kontrasepsi yang banyak jenisnya menyebabkan banyak perempuan mengalami kesulitan dalam menentukan pilihan jenis kontrasepsi yang akan digunakan (Saifudin, 2010). Selain itu dengan banyak jenisnya metode kontrasepsi yang tersedia maka makin banyak pula kemungkinan pilihan yang dapat dilakukan oleh masyarakat dalam ber KB. Akseptor KB juga diharapkan memiliki pengetahuan tentang pelayanan metode kontrasepsi yang digunakan agar dapat membangun sikap dan perilaku yang bertanggung jawab yang berarti akseptor mampu mengetahui mekanisme kerja dan dampak dari metode kontrasepsi yang digunakan (BBKBN, 2006).

Menurut hasil penelitian Sukriani, Priharyanti, W. (2013) didapatkan bahwa terdapat hubungan yang bermakna antara tingkat pengetahuan ibu primipara tentang alat kontrasepsi dengan pemilihan alat kontrasepsi.

Berdasarkan wawancara peneliti pada sekitar 12 orang ibu akseptor KB di Puskesmas didapatkan bahwa alasan pemilihan alat kontrasepsi karena anjuran dari orang terdekat seperti ibu, suami, atau saudara serta dari orang lain yang telah memiliki pengalaman dalam menggunakan KB. Dari hasil ini peneliti 
menyimpulkan bahwa faktor yang mempengaruhi ibu akseptor $\mathrm{KB}$ dalam memilih alat kontrasepsi adalah bukan dari hanya dari pengetahuan tetapi banyak factor yang mempengaruhinya, Data Badan PPKB Kota Mataram tahun 2015 didapatkan bahwa Puskesmas yang memiliki jumlah akseptor KB baru tertinggi adalah Puskesmas Karang Taliwang.

Tujuan penelitian ini adalah untuk mengetahui faktor-faktor dalam pemilihan metode kontrasepsi oleh ibu akseptor KB.

\section{METODE PENELITIAN}

Penelitian ini dilakukan di Puskesmas Karang Taliwang Kota Mataram karena data dari Badan PPKB Kota Mataram tahun 2015, Puskesmas Karang Taliwang merupakan Puskesmas yang mempunyai jumlah akseptor KB baru tertinggi. Jenis penelitian ini adalah observasional deskriptif dengan rancangan cross sectional.

Populasi pada penelitian ini adalah jumlah akseptor KB selama tahun 2015 di Puskesmas Karang Taliwang sebanyak 372 orang. Jumlah sampel penelitian ini adalah seluruh akseptor KB yang melakukan kunjungan ke Puskesmas dengan jumlah 30 orang. Metode pengambilan sampel secara accidental sampling.

Data primer dikumpulkan dengan wawancara menggunakan kuesioner. Selain itu untuk mempertegas jawaban yang didapatkan dari kuesioner dilakukan pula wawancara mendalam / deep interview dengan dibantu menggunakan alat perekam.

Variabel penelitian ini meliputi faktor pengetahuan, social budaya, keagamaan, biaya, dukungan keluarga, dan pendapatan keluarga. Analisis dilakukan secara deskriptif.

\section{HASIL PENELITIAN}

Sampel yang digunakan adalah ibuibu akseptor KB yang menggunakan kontrasepsi sedang datang berkunjung ke Puskesmas Karang Taliwang saat penelitian berlangsung. Jumlah yang didapatkan sebanyak 30 orang sampel yang sudah memenuhi kriteria inklusi dan eksklusi. Distribusi frekwensi masingmasing factor dalam pemilihan metode kontrasepsi secara rinci bisa dilihat pada table berikut : 
Tabel 1.1 Distribusi frekwensi masing-masing factor dalam pemilihan metode kontrasepsi di Puskesmas Karang Taliwang ( $\mathrm{n}=30$ ).

\begin{tabular}{|c|c|c|c|}
\hline Faktor Pemilihan & Kategori & $\mathbf{n}$ & $\%$ \\
\hline \multirow{3}{*}{ Pengetahuan } & Baik & 1 & 3,3 \\
\hline & Cukup & 8 & 26,7 \\
\hline & Kurang & 21 & 70 \\
\hline \multirow{2}{*}{ Budaya } & Ada & 1 & 3,4 \\
\hline & Tidak ada & 29 & 96,6 \\
\hline \multirow{2}{*}{ Agama } & Ada & 4 & 13,4 \\
\hline & Tidak ada & 26 & 86,6 \\
\hline \multirow{2}{*}{ Biaya } & Terjangkau & 30 & 100 \\
\hline & Tidak terjangkau & 0 & 0 \\
\hline \multirow{2}{*}{ Dukungan Keluarga } & Mendukung & 30 & 100 \\
\hline & Tidak mendukung & 0 & 0 \\
\hline \multirow{2}{*}{ Pendapatan Keluarga } & Mampu & 29 & 96,6 \\
\hline & Tidak mampu & 1 & 3,4 \\
\hline
\end{tabular}

Berdasarkan Tabel di atas secara rinci dapat dilihat bahwa pemilihan metode kontrasepsi oleh ibu akseptor KB yang paling tinggi adalah pengetahuan kurang $(70 \%)$, tidak ada pengaruh budaya $(96,6 \%)$, tidak ada pengaruh agama $(86,6 \%)$, biaya terjangkau (100\%), dukungan keluarga (100\%), dan kemampuan pendapatan keluarga $(96,6 \%)$. Dari semua factor-faktor tersebut paling dominan dipengaruhi oleh factor biaya $(100 \%)$, pendapatan keluarga $(96,6 \%)$ dan dukungan keluarga (100\%)

\section{PEMBAHASAN}

\section{Pengetahuan}

Berdasarkan hasil penelitian didapatkan bahwa sebagian besar responden (70\%) berpengetahuan kurang. Responden hanya mengetahui jenis - jenis kontrasepsi tetapi tidak mengetahui manfaat, kerugian, kemungkinan komplikasinya, dan keuntungan/manfaat dari alat kontrasepsi yang dipilih. Hal ini dikarenakan sebagian besar responden sebelumnya tidak pernah mendapatkan penyuluhan mengenai alat kontrasepsi.

Hasil penelitian ini sesuai dengan Notoadmojo (2010) yang mengatakan bahwa pengetahuan hasil tahu setelah seseorang melakukan pengindraan terhadap suatu objek tertentu melalui indera penglihatan, pendengaran, penciuman, perasaan, dan perabaan. Bila seseorang tidak pernah mendapatkan informasi tentang objek tertentu dalam hal ini alat kontrasepsi maka tidak akan bisa mengetahui segala informasi yang berkaitan dengan alat kontrasepsi. Menurut Pendit (2006) tingkat pengetahuan tentang metode kontrasepsi adalah tahu tentang ragam metode 
kontrasepsi yang tersedia, keamanan dan cara pemakaian metode - metode tersebut, kontrasepsi yang mereka pilih, termasuk kemungkinan tentang efek samping dan komplikasinya.

Hasil penelitian ini juga sependapat dengan Hartanto (2004) bahwa semakin baik tingkat pengetahuan seseorang tentang metode kontrasepsi semakin diperhitungkan jenis metode kontrasepsi yang akan digunakan. Selain itu sependapat dengan hasil penelitian yang dilakukan oleh Sumiati (2008) yang menyatakan bahwa ada hubungan antara tingkat pengetahuan seseorang dengan pemilihan jenis kontrasepsi yang akan digunakan.

\section{Sosial Budaya}

Berdasarkan hasil penelitian didapatkan bahwa sebagian besar responden $(96,6 \%)$ mengatakan bahwa pemilihan metode kontrasepsi tidak dipengaruhi oleh faktor sosial budaya.

Hal ini dapat dilihat dari pernyataan yang diberikan oleh responden dimana dari 30 orang responden semua responden menyatakan bahwa tidak ada tradisi baik di keluarga maupun lingkungan dalam penggunaan/pemilihan alat kontrasepsi, 29 orang responden menyatakan bahwa tidak ada adat istiadat yang melarang terhadap penggunaan alat kontrasespi yang dipilih. Hal ini menunjukan bahwa sebagian besar masyarakat di puskesmas karang taliwang tidak di pengaruhi oleh faktor sosial budaya ketika melakukan pemilihan terhadap alat kontrasepsi, meskipun masih ada sebagian kecil masyarakat yang di pengaruhi oleh faktor sosial budaya ketika memilih alat kontrasepsi.

Hasil wawancara mendalam, sebagian besar akseptor KB di Puskesmas Karang Taliwang mengatakan tidak ada larangan dari lingkungan setempat, atau tidak ada kebiasaan yang melarang untuk menggunakan kontrasepsi tertentu. Hasil wawancara tersebut juga menunjukan bahwa tidak ada masyarakat atau anggota keluarga yang mempercayai budaya bahwa banyak anak maka banyak rezeki termasuk juga tidak adanya yang mempercayai budaya bahwa sebuah keluarga tidak akan menggunakan alat kontrasepsi bila belum mempunyai anak laki laki sebagai penerusnya. Budayabudaya seperti itu sudah mulai dihilangkan oleh akseptor KB karena dipengaruhi oleh dukungan keluarga dan suami, dimana akseptor KB akan memilih kontrasepsi sesuai keinginanya dan kemudian keputusanya didukung oleh keluarga sehingga akseptor KB akan lebih mudah untuk membuat keputusan.

Hal ini sesuai dengan hasil penelitian yang dilakukan oleh Erna Ariani (2012) yang mengatakan bahwa tidak ada hubungan yang signifikan antara budaya dan pemilihan kontrasepsi. 
Agama

Berdasarkan hasil penelitian didapatkan sebagian besar responden $(76,6 \%)$ menyatakan tidak ada larangan agama terhadap penggunaan metode kontrasepsi. Hal ini dapat dilihat dari pernyataan responden dimana sebagian besar menyatakan bahwa tidak ada peraturan agama yang menjelaskan tentang pemilihan alat kontrasepsi, bahwa dari agama yang dianut tidak ada larangan terhadap penggunaan alat kontrasepsi yang dipilih. Dari pernyataan diatas menunjukkan bahwa dari sisi agama tidak ada peraturan agama dalam pemilihan alat kontrasepsi dan agama memperbolehkan penggunaan alat kontrasepsi serta tidak ada larangan terhadap penggunaan alat kontrasepsi selagi tujuan dari penggunaan alat kontrasepsi tersebut positif yaitu seperti untuk menjarangkan kehamilan atau membatasi jumlah anak.

Hal ini sesuai dengan pendapat dari Masjfuk (2002) yang mengatakan bahwa Program KB dalam agama dibolehkan (mubah) bisa menjadi sunnah, wajib, makruh, atau haram, sepertinya halnya hukum perkawinan bagi orang islam yang hukum asalnya juga mubah. Kalau seorang muslim melaksanakan KB yang motivasi hanya bersifat motivasi misalnya ber $\mathrm{KB}$ untuk menjarangkan kehamilan / kelahiran atau untuk menjaga kesehatan / kesegaran / melangsingkan badan ibu, hukumnya boleh saja. Tetapi hukum ber KB menjadi makruh bagi pasangan suami istri yang tidak siap menghadapi kehamilan istri, padahal suami tersebut tidak ada hambatan / kelainan untuk mempunyai keturunan. Hukum ber KB juga menjadi haram (berdosa), apabila orang melaksanakan KB dengan cara yang bertentangan dengan norma agama, misalnya dengan cara vasektomi (MOP) dan Abortus (pengguguran).

Hal ini sependapat dengan hasil penelitian Diana Apriani Putri (2014) yang menyatakan bahwa tidak ada hubungan yang signifikan antara keyakinan dengan pemilihan kontrasepsi IUD.

Jadi dapat disimpulkan bahwa faktor agama tidak mempengaruhi dalam pemilihan alat kontrasepsi karena agama tidak melarang penggunaan alat kontrasepsi apapun selagi tujuan dari penggunaan alat kontrasepsi mengarah ke tujuan yang baik.

Biaya

Berdasarkan hasil penelitian didapatkan semua responden (100\%) menyatakan bahwa biaya untuk mendapatkan alat kontrasepsi masih terjangkau. Hal ini sesuai pernyataan responden dimana yang menyatakan bahwa penggunaan alat kontrasepsi membutuhkan biaya yaitu jenis alat kontrasepsi KB suntik, pil, steril dan IUD meskipun tergolong mahal masih tetap dapat dijangkau tetapi sebagian alat kontrasepsi tersebut tidak membutuhkan 
biaya atau ditanggung oleh pemerintah/menggunakan kartu jaminan (gratis). Hal ini menunjukkan dikarenakan pengetahuan responden yang kurang sehingga meskipun biaya dari alat kontrasepsi tergolong mahal namun tetap dapat dijangkau oleh responden dan tetap memilih alat kontrasepsi yang membutuhkan biaya demi kenyamanan yang dirasakan tanpa memikirkan kegunaan, manfaat serta kemungkinan komplikasi yang akan terjadi.

Hal ini sesuai dengan Prawirohardjo (2005) yang menyatakan bahwa harga obat atau alat kontrasepsi yang terjangkau menjadi faktor yang menentukan akseptabilitas cara kontrasepsi. Lebih lanjut dijelaskan bahwa kontrasepsi ideal harus memenuhi syarat-syarat tertentu, diantaranya adalah murah harganya sehingga dapat dijangkau oleh seluruh lapisan masyarakat.

Dukungan Keluarga

Berdasarkan hasil penelitian
didapatkan semua responden (100\%)
mendapatkan dukungan dari keluarga
khususnya suami dalam pemilihan alat
kontrasepsi. Hal ini dapat dilihat dari
pernyataan responden dimana semua
responden mengatakan bahwa keluarga
mendukung terhadap pilihan alat
kontrasepsi yang dipilih dan bentuk
dukungan keluarga yang diberikan berupa
memfasilitasi ibu baik dari memberikan
biaya untuk pemasangan KB,

mengantarkan ibu untuk memasang $\mathrm{KB}$ ataupun memberikan persetujuan terhadap penggunaan alat kontrasepsi yang dipilih. Dalam hal ini sebagian besar responden memilih alat kontrasepsi sangat tergantung pada dukungan suami karena suami yang menjadi kepala keluarga.

Program KB dapat terlaksana dengan baik apabila mendapat dukungan dari pihak-pihak tertentu. Perilaku atau tingkah laku orang banyak dipengaruhi oleh orang - orang yang dianggap penting. Apabila seseorang itu penting untuknya, maka apa yang ia katakan atau perbuat cenderung atau dicontoh.

Hal ini sesuai dengan Notoatmodjo (2010) yang mengatakan seseorang ibu dalam memilih alat kontrasepsi sangat tergantung pada dukungan suami karena suami pengambil keputusan dalam keluarga. Orang-orang yang dianggap penting ini disebut kelompok referensi. Bentuk partisipasi suami dalam penggunaan alat kontrasepsi adalah mendukung istri dalam memilih alat kontrasepsi dan memberikan kebebasan kepada istri untuk menggunakan kontrasepsi tersebut (BKKBN, 2008).

Hal ini sependapat dengan hasil penelitian Hery Aryanti (2014) yang menyatakan bahwa ada hubungan yang bermakna antara dukungan suami dengan penggunaan alat kontrasepsi pada wanita kawin usia dini di Kecamatan Aikmel Kabupaten Lombok Timur. 
Jadi dapat disimpulkan bahwa responden memilih kontrasepsi sesuai dengan pendapat yang menjelaskan bahwa perilaku seseorang dalam menentukan jenis kontrasepsi yang digunakan sangat tergantung pada orang penting sebagai referensi.

\section{Pendapatan Keluarga}

Berdasarkan hasil penelitian didapatkan sebagian besar responden $(96,6 \%)$ pendapatan keluarga yang didapatkan dapat menjangkau biaya dari alat kontrasepsi. Hal ini dapat dilihat bahwa sebagian memiliki penghasilan rata-rata yang tinggi dalam sebulan namun sebagian meskipun memiliki penghasilan yang rendah masih dapat disisihkan untuk biaya penggunaan alat kontrasepsi yang dipilih. Hal ini menunjukkan bahwa penghasilan atau pendapatan keluarga mempengaruhi ibu akseptor KB memilih alat kontrasepsi yang hanya dapat dijangkau dari penghasilan atau pendapatan keluarga yang didapatkan tanpa memikirkan apakah kontrasepsi yang dipilih sesuai atau tidak untuk digunakan oleh ibu tersebut.

Hal ini sesuai dengan pendapat dari Utami (2011) yang menyatakan bahwa tingkat pendapatan biasanya berupa uang yang dapat mempengaruhi dalam pemilihan kontrasepsi. Pendapatan yang cukup dapat memperoleh kualitas pelayanan kesehatan khususnya KB.
Hal ini juga sependapat dengan hasil penelitian Maya Cobalt Angio S (2011) yang menyatakan bahwa terdapat hubungan yang signifikan antara tingkat penghasilan dengan pemilihan alat kontrasepsi hormonal.

Jadi dapat disimpulkan bahwa pendapatan merupakan suatu persoalan yang berhubungan erat dengan daya upaya manusia dalam memenuhi kebutuhan hidup di masyarakat, terutama kebutuhan untuk ber $\mathrm{KB}$ demi untuk menjarakkan jumlah anak.

\section{KESIMPULAN}

Berdasarkan hasil penelitian dapat disimpulkan bahwa pemilihan metode kontrasepsi oleh akseptor KB lebih banyak didominasi oleh factor-faktor sebagai berikut :

1. Tidak dipengaruhi oleh factor budaya.

2. Biaya yang terjangkau.

3. Dukungan keluarga.

4. Pendapatan keluarga.

\section{SARAN}

Setiap kegiatan penyuluhan atau konseling KB pada akseptor agar dalam pemilihan metode kontrasepsi perlu memperhatikan adanya factor budaya, biaya, dukungan keluarga dan pendapatan keluarga.

\section{DAFTAR PUSTAKA}

BKKBN, 2006. Analisis Kelangsungan Pemakaian Kontrasepsi. Jakarta. 
BKKBN. Prov.NTB. 2014, Jumlah Peserta KB Aktif Per Mix Kontrasepsi Menurut PUS. NTB.

BPPKB. Kota Mataram. 2014. Jumlah Peserta KB Kota Mataram.

Glasier, Anna Dan Alias Gebbie, 2005, Keluarga Berencana Dan Kesehatan Reproduksi, EGC : Jakarta.

Hartanto, Hanafi, 2004. Keluarga Berencana Dan Kontrasepsi. Pustaka Sinar Harapan : Jakarta.

Notoadmodjo, Soekidjo, 2007. Ilmu Kesehatan Masyarakat. Rineka Cipta : Jakarta.

Pendit, 2006. Ragam Metode Kontrasepsi. EGC : Jakarta

Prawirohardjo, Sarwono, 2008, Ilmu Kandungan, Jakarta : YBP.

Setya, Arum dan Dian Novianti, 2009. Panduan Lengkap Pelayanan KB, Mitra Cendikia : Yogyakarta.

Saifudin, A.B. 2006. Buku Panduan Praktis Pelayanan Kontrasepsi, Yayasan Bina Pustaka Sarwono : Jakarta.

Angio maya cobalt 2011, http://pmb.stikestelogorejo.ac.id/ej ournal/index. php/ilmukeperawatan/article/view/ 65 Diunduh tanggal 28-06-2016.

Ariani Erna, 2012, http:/opac.say.ac.id/1510 Diunduh tanggal 07-2-2016

Maula, aminatul 2014,Http://Karyatulisilmiah.Com/ Faktor-Faktor-Yang Mempengaruhi-Pemilihan-AlatKontrasepsi. Diunduh tanggal 2806-2016

Putri Diana apriani 2014, Http://Opac.Unisayogya ac.id/945/1/NASKAH\% 20PUBLIKASI.Pdf. Tanggal 28-06-2016
Sukriani dan Priharyanti Wulandari 2013, Http://Jurnal.Unimus.ac.id/ Index. Php/Psn12012010/Article/View/14 50/1503. Diunduh Tanggal 06-10$\underline{2015}$ 